https://doi.org/10.18485/iipe_60nam.2021.ch4

\title{
INDIA AND NON-ALIGNMENT - FORMATIVE YEARS
}

\author{
Amit DAS GUPTA ${ }^{1}$
}

\begin{abstract}
Prior to India's independence, Jawaharlal Nehru declared nonalignment to be the guiding principle of Indian foreign policy. The same approach is taken by the current government of India, which adheres to this tradition. This chapter shows that non-alignment meant very little right from the start, as it was neither defined nor did it give any practical guidance for a general course or individual cases. On the contrary, a rivalling concept for an aligned foreign policy, authored by the Ministry of External Affairs first Secretary-General G.S. Bajpai, was based on a quartercentury of experience on the international floor and breathed deep realism. While Nehru over the years left it mostly with commonplaces, Bajpai's realism occasionally surfaced both in the prime minister's statements and Indian foreign policy. Early decision-making, decisions and non-decisions in the cases of China and Germany show confusion in the upper ranks of the Indian Foreign Service. Finally, national interest was pursued for pragmatic or economic motives, although the term was strictly avoided in the public as it contracted the Nehruvian idea of uniqueness and idealism.

Key words: India, Non-alignment, Realism, national interest, Cold War, Germany, China, Nehru
\end{abstract}

\section{Introduction}

No analysis of the foreign policy of independent India can skip over the term non-alignment. Many studies on the country's foreign affairs celebrate non-alignment as a genuine, smart Indian concept and a major contribution to global affairs, especially during the Cold War, allowing a more or less

\footnotetext{
${ }^{1}$ Senior Researcher, Universität der Bundeswehr München, Germany. E-mail:amitrdasgupta@gmx.de
} 
independent course in years of economic underdevelopment and relative military weakness. By all means, non-alignment has been used as a synonym for Nehruvian foreign relations. Until today, it officially defines Delhi's course in international affairs. Therefore, India has always been ascribed a leading role in the Non-Aligned Movement. The difficulty arises when one attempts to find a closer definition of Indian non-alignment, then and today. Apart from staying away from military pacts, Indian non-alignment has always been open for interpretations. As Keenleyside shows, there have been various attempts to give some meaning to it. Indeed, if the term ever was defined, it was by scholars and retired diplomats, mostly belatedly and more than once rather unconvincingly trying to explain that whatever course India had taken in a particular constellation, it remained non-aligned (Keenleyside, 1980, 461-483). One early explanation was to choose a stand by the merit of every individual case. Later, equidistance to both power blocs was considered essential, although establishing such a position stood clearly against the claim of maximum freedom of decision. Indeed, it forced India to balance any step that might be considering favouring one Cold War camp. Whenever the country was considered too close to the West, some leading representative would issue some anti-Western statement in Moscow; notably, no such pattern was seen in the reverse. Such ambiguity rooted in Nehru's often complained Hamletian vagueness. The prime minister never formulated a doctrine of non-alignment. In the internal communication of the MEA, until deep into the 1950s, neutralism or neutrality were used synonymously to non-alignment.

The problem starts with the term itself: Precluding any military alliance - the essence of being non-aligned - leaves many options open and is not tantamount to pursuing a definite course. A non-policy is not a policy yet. To no surprise, there has been, and is, little discussion whether it was wise to choose non-alignment as the guiding principle of foreign affairs, after all. In a lucid criticism of non-alignment, Jayanta Kumar Ray has summarised references of various Indian governments regarding their understanding of the term: Nehru wanted to preserve, first, political independence, second, world peace and, finally, independence of opinion and action on every issue. Ray analyses that an aligned foreign policy pursues the first two aims as well. Furthermore, no government will ever admit that alignment might hamper their full freedom of decision. Moreover, "no country, aligned or non-aligned, can enjoy absolute independence in any case" (Ray, 2011, p. 25). Ray concludes that non-alignment is nothing but realpolitik, be it India or other countries (Ray, 2011, Ibid). Historians of South Asia are well advised to accept this explanation. The Indo-Soviet Treaty of Friendship and 
Cooperation of 1971 came dangerously close to a military alliance, allowing Indira Gandhi to fight a blitzkrieg in then East Pakistan. Earlier, after India's military defeat in the war against the People's Republic of China in 1962, the immediate, as well as the ongoing military threat emanating from Beijing, could be countered only due to support from both Moscow and Washington. Finally, India's development policy could not have been pursued without essential financial and technical support by industrialised countries in Western Europe and North America, even without a military alliance creating an enormous economic dependence on donor countries, which were nearly all members of the Western military pacts. It would be easy to name numerous similar well-known examples in Indian history throughout the Cold War. This chapter looks into the formative years of Indian non-alignment when a debate on realpolitik versus non-alignment took place. On the basis of lesser-known cases, it further shows how India in the years shortly after independence pursued its national interest while knowingly ignoring the principles and morale. It concludes with a short overview of the later years of the Nehruvian foreign policy.

\section{Alignment versus Non-alignment}

The concept of not aligning a country's policy with others can be traced back to the Congress of Vienna of 1815 when the neutrality of Switzerland was recognised by the European powers. It meant that the country would keep out of the conflicts of others under all circumstances. Such a policy found much sympathy in late colonial South Asia. Indian soldiers had fought the British wars in Asia throughout the $19^{\text {th }}$ century. During the First World War, they formed the largest freelance army in history. All this had been financed by the Indian taxpayer. Furthermore, European affairs and colonial policy between 1914 and 1945 abhorred Indian nationalists. Influenced by Marx and Lenin, they saw imperialism and the pursuit of national interest as the main sources of tensions and war. Allegedly, the Western civilisation was driven by materialism, whereas Asia and, in particular, India stood for superior spirituality. M.K. Gandhi held that India had little to learn from Western modernity. Against the background of the downfall of Europe in ruinous wars, India was considered to have a civilising mission for mankind as a whole. This, combined with the country's size, population and a strategic position, made nationalists consider India a potential great power. Therefore, all ideas on a future Indian foreign policy were based on the assumption of strength (Keenleyside, 1980, 461-483). Much of this can be found in the thinking of Jawaharlal Nehru already 
before he became India's first prime minister. Historiography proves, however, that the utterances of politicians on foreign affairs while not yet having any influence on their formulation or implementation count little. Only the experience of exercising actual power with the establishment of the Indian Interim Government in September 1946, led by Nehru as vicepresident, set practical considerations in motion. It turned out that, notwithstanding various earlier statements on global and Indian foreign affairs, India's new leader had hardly any idea on the subject. On 5 December 1946, he admitted that "our policies . . . seem to be rather confused, and there is a tendency to adapt ourselves to this or that varying policy initiated by others. To some extent this is inevitable, but this should not be allowed to go far". In any case, India should not be party "to British foreign policy or the old methods of the British Foreign Office ... Our policy will be determined by us later" (Nehru Memorial Museum and Library (NMML), M.O. Mathai Papers, Correspondence with K.P.S. Menon. Letter, Nehru to K.P.S. Menon, 5 December 1946 (NMML, 1946). Indeed, India inherited much of British policy, and not only politics in the areas neighbouring the subcontinent. Early that year, on the other side of the globe, another Indian had authored a comprehensive foreign policy concept, which stood in sharp contrast to the ideas of Indian nationalists as outlined above. Girja Shankar Bajpai, agent-general of British India in Washington D.C., looked back to a quarter-century in international diplomacy. An officer of the elite cadre of the Indian Civil Service from 1921, he had attended numerous international conferences and meetings of the League of Nations, pursuing a comet-like career mostly in the context of the policy around Indians overseas. He was the first Indian official to be appointed secretary and later head of a department (Das Gupta, 2021, pp. 28-34). Due to his extraordinary skills as a negotiator, he, among others, had made racist South Africa participate in two round table conferences, which, for the time being, ended the discrimination of people of Indian origin (Das Gupta, 2021, pp. 47-71). In 1942, his transfer to Washington was actually degradation. Nevertheless, it also brought him in close touch with nearly every conference shaping the early stages of the Cold War (Das Gupta, 2021, pp. 150-169). Therefore, India's leading foreign policy expert at the eve of independence was not Nehru, lacking practical experience in diplomacy and international affairs. It was Bajpai, ironically, heavily engaged in anti-Congress propaganda during the world war. In the interwar period, Bajpai had represented a political entity unable to exercise any pressure. Unlike South Africa, British India enjoyed no dominion status. Furthermore, it could not impose any economic sanctions, let alone threaten with force. Vis-à-vis 
Pretoria, therefore, Bajpai's strategy was much of a continuation of Gandhi's: Distinguished Indian individuals convinced their European counterparts that they conversed on eye level. Like civil rights activists, they had to appeal to their sense of fairness. (Das Gupta, 2021, p. 4). What Bajpai had learned by heart was diplomacy from an inferior position. Notwithstanding all Nehruvian rhetoric, this proved to be realistic for the decades to come; but it stood diametrically against the nationalist belief that India would conduct its foreign affairs from a position of strength. Accordingly, Bajpai's concept of 1946, formally a quarterly report from Washington, started from the assumption that independent India needed strong partners or allies. "A combination of the weak", i.e., with China or the Middle East countries would not provide "the complimentary strength that India will need", he argued. Delhi had to consider a close partnership with one of the great powers - the US, the USSR or the UK. The Soviet Union, however, would undermine Indian democracy, whereas Washington was incalculable and immature. Whatever wrongs in the past, only the British Commonwealth offered a partnership at eye level and to mutual benefit. "Sentiment must serve, not master the national interest" was the concluding sentence, the credo of a realist (BL, 1945). This model concept of realist thinking and even more the term "national interest" should have been anathema to Indian nationalist politicians and Nehru. Many of the later prime minister's statements and actions in international affairs were driven less by logic, but rather by predispositions and emotions, often pride. Whether Nehru ever read the analysis is unknown. Though the head of the External Affairs Department from September 1946, he was overburdened as a party leader, manager of the transfer of power and the failed effort to establish cooperation with the Muslim League in order to prevent the split-up of British India into the Indian Union and Pakistan. It was the combination of too many tasks, the disappointment about the performance of Indian representatives among others at the United Nations, and, finally, the lack of a concept of foreign policy that made Nehru ask for Bajpai's services. The very same day he admitted that he had no clue which course to pursue, he called back India's highest-ranking civil servant to establish the Ministry of External Affairs (MEA) and the Indian Foreign Service (SWJN, 1946, pp. 549550). From the spring of 1947, the two very protagonists of antagonistic schools of thinking on foreign affairs came to work together closely. Nehru's ideas on foreign affairs remained vague, as his first speech on the issue to the Constituent Assembly on 4 December 1947 shows. The prime minister admitted that nothing much had been achieved that far. A year ago, it was stated that "we will not attach ourselves to any particular group". He 
elaborated that "ultimately foreign policy is the outcome of economic policy", but until India "has properly evolved her economic policy, her foreign policy will be rather vague, rather inchoate, and will rather grope about". To say that India stood for peace and freedom that far was a commonplace, found with every country. India should pursue a course "what is most advantageous to her", though no "narrow national policy .. . We propose to look after India's interests in the context of world cooperation and world peace" and make friends with other countries "unless they themselves create difficulties", including the US and the USSR (SWJN, 1946, pp. 549-603). Though the term itself was avoided, there surfaced national interest, which was clearly defined by economic policy, a key consideration for any developing country. Three years later, he confirmed that ideologies had no actual relevance. India should look after its own interests (Nehru, 196, pp. 135-136). Nehru struggled with his insight that India needed to pursue its national interest on the one hand and his idealistic beliefs on the other. More than once, this clashed with Bajpai's straightforward realism. Having been trained in the Indian Civil Service, the new secretary-general of the MEA made it a point to give in whenever there was open dissent (Gundevia, 1984, pp. 89-90). Due to his and his confidants' influence, the tendency towards realpolitik and alignment regularly surfaced throughout the Nehruvian Era, though often thwarted by the emotional decisions of the prime minister. Nehru wanted to be an innovator in international affairs, a claim closely linked with his general idea of modernity (Zachariah, 2004, pp. 7-10). Apart from rhetoric, however, initially, there was little innovation.

\section{Non-aligned Vagueness versus Realism}

When during the world war a Japanese invasion of India had appeared imminent, Gandhi had suggested that the Japanese would not enter the subcontinent if the British left and the Indians laid down their arms (Puri, 1977, pp. 44-45). Nehru did not go that far and maintained armed forces. At the same time, he was convinced that aggression could best be prevented by staying out of military pacts. In his eyes, the best defence policy was to establish a friendship with a potential rival (Das Gupta, 2021, pp. 45-246). When in 1950 Bajpai wanted to forge a military alliance with Burma, whose border was challenged by the People's Republic of China, too, Nehru turned the initiative down. He held that there was "no urge for the Chinese to go to war with a neighbouring country unless that country deliberately joined a power which is hostile to China" (MEAA, 1950). The following year, 
guided by the terms of the peace treaty, the prime minister declared that "Japanese security can best be secured by disarmament." (NAUK, 1951). There seemed to be an obvious contradiction in this approach: If a country needed to prepare its defence, why should it not increase its strength by finding allies? Nehru obviously referred to European military alliances before the First World War. Their mutual assistance clauses had led to the automatism of military mobilisations and a global war. Nehru wanted to secure the maximum freedom of decision, avoiding exactly such automatism. The military defeat in the war with the PRC in 1962 showed that there was more to military alliances: Any signatory could be pulled into a conflict which had been initiated between others on the one hand; on the other hand, in the case of a military attack on India, an alliance would also have guaranteed immediate support by the allies. This was dearly lacking in late 1962. The Nehruvian idea of non-alignment was essentially based on the belief that India was strong enough to defend itself against any aggressor. The logical conclusion that this precondition made the Indian idea of non-alignment incompatible for other, weaker countries was never drawn by the prime minister. On the contrary, he urged others to follow the Indian example. As early as 1951, the realist Bajpai warned Nehru "that there was such a thing as tempting providence", though to no avail (NAUK, 1951). The early years of Nehruvian non-alignment were hardly characterised by the principles and morale, let alone decisiveness. Delhi avoided committing itself to major Cold War questions. Among them, the recognition of divided states was highly relevant. Scholars have praised Indian equidistance to both Koreas and both Vietnams, Delhi recognising none (Misra, 1966). It appears, though, that Delhi was rather happy not having been asked to take a stand and, therefore, being able to remain an observer. This is indicated by the two cases when India recognised one party in China and Germany respectively. With the second Asian giant an immediate neighbour, Delhi simply could not stay aloof ((Das Gupta, 2021, p. 230). Over many years, the bonds between the Indian National Congress and the Guomindang had been as close as those between Nehru and Chiang Kai-Shek. Therefore, since 1942, British India maintained an agency general in Chungking and later Nanking, which was upgraded to an embassy in 1946. Over his 5-year term, Ambassador K.P.S. Menon met Mao Tse-dong at least once, and that at the San Francisco Conference in the US (NMML, 1945). The staunch support of Nationalist China vanished the moment when it was evident that the Communists would win the civil war. Notwithstanding the initial hostile attitude of the future rulers towards foreign diplomats, Menon's successor K.M. Panikkar was ordered to stay 
on and establish contact with the new government. On 30 December 1949, India recognised the People's Republic of China. This was a deeply pragmatic decision. Notwithstanding severe criticism of corruption and mismanagement of the Guomindang Government, the Nehru government had no sympathies for communists. Indeed, the Communist Party of India was considered the very enemy of the new political order. Furthermore, new China was an unknown quantity on the global floor, its foreign policy unpredictable. There was no lack of warnings among Indian China experts that the PRC would soon occupy Tibet and revive traditional Chinese claims regarding the southern slopes of the Himalayas (Das Gupta, 2017, pp. 267270). Bajpai and Home Minister Sardar Vallabhbhai Patel suggested linking the recognition with an acceptance of the border as India defined it. They further wanted to secure the border areas with a military build-up. The prime minister, however, turned those suggestions down, holding that the best defence against possible conflicts would be to make friends with the new leadership in Beijing (Dasgupta, 2014, pp. 717-724). Believing in nonviolent solutions was truly Nehruvian. It was less Nehruvian principles, though, to drop a close friend (Chiang Kai-shek). Finally, to take sides between two deeply antagonistic Chinese governments was not in line with non-alignment. The truth was that other than the PRC, far-away Taiwan was of no concern to India. Pragmatism overruled principles. This can be seen even better with another recognition issue the same year. The creation of two German states was of little immediate concern for Delhi, which in those days pursued but economic interests in Europe. In 1948, India concluded a trade agreement with the western occupation zones, whereas it had met indifference in the Soviet occupation zone. Like China, India had inherited a military mission in the British sector of Berlin. When in September the Federal Government established itself in Bonn, on request of the Western Powers, India opened an office there. However, India continued to accredit a representative to the Allied High Commission, officially the highest body of the Federal Republic of Germany (FRG). What within a few months later was considered the recognition of the new country was then handled as a mere bureaucratic act, approved by Bajpai, whereas the prime minister had not been involved. When the German Democratic Republic (GDR) was created in the East of Germany in October, neither East Berlin nor Moscow asked Delhi for recognition of the GDR. Non-action like in Korea or Vietnam would have been sufficient (Das Gupta, 2019, pp. 101117). It was India's representative in Berlin, Khub Chand, who authored the document which clarified where India's interests lay in divided Germany. A junior former officer of the colonial ICS with no experience in international 
affairs and even less standing in Delhi, he hit the nail on the head, though in a manner that was never permitted to become public. He brushed away principles, legal arguments or the question of the legitimacy of the East German government, had India and the Western Powers well recognised the puppet regimes in the Soviet satellite states. Instead, he emphasised the taboo term "national interest", even linking it with close cooperation with the US: "All the logic and all the loyalty to principles in the world will defeat their own ends if the country goes under. We are deeply interested in financial and technical assistance from the United States; otherwise, we run the risk in ten or fifteen years of an internal revolution fed on hunger and distress. We must not, therefore, turn Congress and private American businessmen from the task of Indian reconstruction by premature and illconsidered political moves in Europe". India should establish trade relations with East Germany, but otherwise pursue a policy of wait and see. Even if the new regime has gained a popular mandate, India should act here when it has to (NAI, 1949). The MEA approved, Foreign Secretary K.P.S. Menon considering the analysis "sound" (NAI, 1949). It was British comments which finally triggered a discussion among MEA officials on the merits of the case. London let Delhi know that it did not consider the newly installed regime heading a proper state. Whereas the FRG enjoyed far-reaching, though not complete sovereignty, the Soviets kept on controlling everything in East Germany, where no elections had taken place. Therefore, the UK repudiated the East German claim to represent the whole of Germany (NAI, 1949). Only the freely elected Federal Government spoke for all Germans, including those in the Soviet occupation zone, currently truncated from the rest of Germany (NAI, 1949). In a formal reply, Menon informed that India pursued a wait-and-see strategy, would promote trade and deal with East German authorities on an ad hoc basis "without getting involved in questions of formal recognition" (NAI, 1949). Though nothing was patronising in the letters of the former colonial power, they definitely hit a nerve. The Indian internal discussion remained inconsequential, but it revealed that two years after independence, nobody in the MEA had a concrete idea of what exactly non-alignment meant or how to implement its alleged meaning into practical politics. Deputy Secretary S.K. Banerji understood it as a "policy of neutrality between the two blocs". Therefore, "when necessary", India "should be prepared to give equal recognition to the Democratic Govt. of East Germany as well" (NAI, 1949). Menon came to the same conclusion, though emphasising logic: "We have not been exactly logical in recognising the West German Government, set up under the Allied High Commission while refusing to recognise the South Korean 
Government, which has been set up under the aegis of the United Nations. We do not want to commit a further illogicality by recognising the West German Government and refusing to recognise the Government of East Germany" (NAI, 1949). Joint Secretary C.S. Jha, finally, considered equidistance to both blocs the essence of non-alignment. He held that India could not subscribe to the British arguments "without laying ourselves open to a charge of partisanship with the western bloc" (NAI, 1949). Later on, Bajpai formulated internal guidelines for India's Germany, which have kept valid for more than two decades: "However illogical this may sound, our exchanging diplomatic representatives with East Germany will not only be misunderstood by the West German Government . . . but will retard rather than hasten the process of unification, which is the rational and natural objective. The more powers give formal recognition to the existence of two German Governments by accrediting diplomatic representation to each, the greater will be the tendency for the two German states to continue as separate entities" (NAI, 1954). This argumentation, used in public as well, referred to the right of self-determination, only too naturally a sacred cow for a former colony. It lacked logic, however, as Deputy Secretary A.J. Kidwai noted in another internal note in 1955: "Our recognition of West Germany is as much recognition of the division of Germany, and if we wanted to take a stand on German unification, we should not have recognised West Germany. Therefore, it seems to me that we have taken a wise action for the wrong reason, or perhaps, very wisely, given the world the wrong reasons for it. We avoid recognising East Germany not because of principle but on grounds of expediency" (NAI, 1954). In sum, India's policy regarding Germany tried to maintain a façade of moral high ground and principles. Indeed, economic and financial considerations, correctly translated as national interest, a term disdained by Indian nationalists, stood in the background of the decision to recognise West but not East Germany in 1949. It tells a story that the term was well used in internal communication - no reasonable official could deny Indian dependency on trade and aid from the West - but was strictly avoided in public statements. Nonalignment as understood by leading officials of the MEA de facto played no role at all: India's stand was neither logical nor neutral - indeed, the country in one of the highly relevant issues of the early Cold War clearly opted for the Western bloc. This was in full harmony with India's European policy throughout the Nehru years. Due to a similar political system, personal experiences of its elites, particularly in France and the UK, and a partly similar mindset thanks to British education, India, mostly with much sympathy, closely cooperated with West European countries, including 
most of the colonial powers. On the contrary, the governments of the people's republics in the Soviet sphere were despised. Reports from Prague, where India for a long while maintained the only embassy apart from the one in Moscow, even after Stalin's death regularly saw brutal dictatorships using Stalinist methods.

\section{Conclusions}

Indian foreign affairs won some more shape in the mid-1950s. After the country played an extraordinary role in the context of the Geneva Peace Conference on Indochina, non-alignment seemed to come to fruition. Delhi also found some closer cooperation with the two other countries promoting a non-aligned foreign policy, Egypt and Yugoslavia. Nevertheless, Nehru only hesitatingly joined the Afro-Asian Conference at Bandung in 1955, only to be outsmarted by his Chinese counterpart Zhou En-lai. When the Nonaligned Movement came into being at the Belgrade Conference in 1961, India, once again, played a rather defensive part, preventing too radical resolutions. India's border conflict with China has de facto ended its non-aligned position. The UK and the US offered immediate support and military hardware, not much later the USSR became the major provider for the Indian Air Force. After China exploded its first nuclear device in 1964, Nehru's successor Lal Bahadur Shastri was after a nuclear umbrella by both superpowers, often termed double-alignment. Finally, the Bangladesh War in December 1971 could not have been fought and won without Moscow counterbalancing threats from Beijing and Washington. Nevertheless, Delhi had also assured the tacit support of Western European countries, which went on providing substantial loans for India's economic development and quickly recognised Bangladesh, thereby allowing Indira Gandhi to reduce her dependence on the USSR. This decade of Indian foreign affairs was clearly characterised by realpolitik. If non-alignment still meant staying away from military alliances, it played a subordinated role at best. Every time Delhi clearly left a position of equidistance from the blocs, accepting military aid and more, Indian governments declared to be keen to recalibrate the country's stand in global affairs. Nevertheless, they had learned the lesson that when things came to a close like in 1962, they could not count on their non-aligned friends (Čavoški, 2017, pp. 160-178). Nevertheless, Nehruvian non-alignment remained the key term in every Indian government's statement, and this is true until today. As this chapter shows, non-alignment had little meaning in the formative years of the foreign affairs of independent India. The Nehru government was rather clueless as to what line to pursue and shy to use the 
term 'national interest'. The result was indecisiveness on many levels of the administration and in many relevant issues.

\section{References}

BL. (1945). British Library, India Office Records (IOR), L/PS/12/4627. Quarterly Report October to December. Bajpai.

Čavoški, Jovan (2017). Saving Non-alignment. Diplomatic Efforts of major non-aligned countries and the Sino-Indian Border Conflict, in: Amit R. Das Gupta and Lorenz M. Lüthi (eds.), The Sino-Indian War of 1962. New Perspectives. New Delhi, Routledge.

Das Gupta, Amit (2017). Serving India. A political Biography of Subimal Dutt (1903-1992), India's longest serving Foreign Secretary. New Delhi, Manohar.

Das Gupta, Amit (2019). The Fateful Indian Recognition of West Germany, 1949, Cold War History, 19/1.

Das Gupta, Amit (2021). The Indian Civil Service and Indian Foreign Policy, 1923-1961. New Delhi, Routledge.

Dasgupta, Chandrashekhar (2014). Nehru, Patel and China, Strategic Analysis, 38/5.

Gundevia, Yezdezard Dinshaw (1984). Outside the Archives. Hyderabad, Sangam Books.

Keenleyside, T.A. (1980). The Meaning of Non-Alignment before Indian Independence, Pacific Affairs, 53/3.

MEAA. (1950). Ministry of External Affairs Archives, 48-SB/50. Letter, K.M. Kannampilly to Dutt, 6 November.

Misra, Kashi Prasad (1966). India's Policy of Recognition of States and Governments. Bombay, Allied Publishers.

NAI. (1949). National Archives of India, MEA, 5(115)-EURII/49. Letter, Khub Chand to K.P.S. Menon, 19 October.

NAI. (1949). National Archives of India, MEA, 5(115)-EURII/49. Letter, Roberts to K.P.S. Menon, Emphasis in the original, 28 October.

NAI. (1949). National Archives of India, MEA, 5(115)-EURII/49. Letter, Pritchard for P.N. Haksar, Indian High Commission London, 4 November.

NAI. (1949). National Archives of India, MEA, 5(115)-EURII/49. Letter, K.P.S. Menon to Roberts, 16 November. 
NAI. (1949). National Archives of India, MEA, 5(115)-EURII/49. Note, K.P.S. Menon, 28 October.

NAI. (1949). National Archives of India, MEA, 5(115)-EURII/49. Note, Banerji, 9 November.

NAI. (1949). National Archives of India, MEA, 5(115)-EURII/49. Note, K.P.S. Menon, 12 November.

NAI. (1949). National Archives of India, MEA, 5(115)-EURII/49. Note, Jha, 30 November.

NAI. (1954). National Archives of India, MEA EII/54/1811/63. Note, Bajpai, undated, quoted in Note, A.J. Kidwai, 12 April.

NAUK. (1951). National Archives of the United Kingdom, Foreign Office (FO), 371/92889. Record of Interview, 15 Januar.

Nehru, Jawaharlal (1961). India's Foreign Policy, Selected Speeches, New Delhi, GOI.

NMML (1945). Nehru Memorial Museum and Library, K.P.S. Menon Papers, Diary 1945, 28 May.

NMML. (1946). Nehru Memorial Museum and Library, M.O. Mathai Papers, Correspondence with K.P.S. Menon. Letter, Nehru to K.P.S. Menon, 5 December.

Puri, Rashmi-Sudha (1977). Gandhi and the Second World War, The Indian Journal of Political Science, 38/1.

Ray, Jayanta Kumar (2011). India's Foreign Relations, 1947-2007, New Delhi, Routledge.

SWJN. (1946). Selected Works of Jawaharlal Nehru, vol. 1, vol. 4. New Delhi, Nehru Memorial Museum and Library.

Tripathi, Manjul Rani (1990). India's Foreign Policy on Diplomatic Recognition of States and Governments. Delhi, B.R. Publishers.

Zachariah, Benjamin (2004). Nehru. New Delhi, Roli Books. 